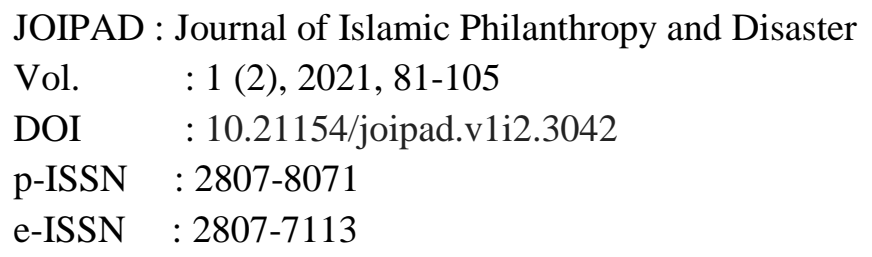

\title{
Efektifitas Penyaluran Zakat Pada Masjid Darussalam Kota Wisata Cibubur
}

\section{Rifqi Chairul Umam¹, Ade Nur Rohim², Siwi Nugraheni ${ }^{3}$}

${ }^{123}$ Universitas Pembangunan Nasional Veteran Jakarta, Indonesia, rifqi.chairul@upnvj.ac.id, adenurrohim@upnvj.ac.id, siwinugraheni@upnvj.ac.id

\begin{abstract}
Zakah is one of the pillars of Islam that must be implemented, zakah is generally divided into 2, zakah maal and zakah fitrah. A mosque is a place for Muslims to perform worship both in congregation and individually. In Indonesia the mosque is also a place for collecting and distributing zakat funds. This study aims to identify the effectiveness of zakat distribution through mosques (case study of Darussalam Mosque, Kota Wisata, Cibubur). The research method used is descriptive qualitative research methods with primary and secondary data sources that will be obtained from interviews, viewing reports related to zakat, observations, and documentation to Amil in Masjid Darussalam, Kota Wisata, Cibubur. The results of the study show that all indicators, that is right on target, economic improvement, use of funds. with some notes that need to be considered, namely the ZakatPro program must be carried out carefully monitoring and coaching so that mustahik can be more productive, and provide solutions to each mustahik's business problems.
\end{abstract}

Keywords: Effectiveness, Mosque, Zakah Distribution. 


\begin{abstract}
Abstrak
Zakat merupakan rukun Islam ke tiga yang harus dilaksanakan, zakat secara umum terbagi 2 yaitu, zakat maal dan zakat fitrah. Masjid merupakan tempat umat muslim untuk melakukan ibadah baik secara berjamaah maupun individu. Di Indonesia masjid juga merupakan tempat penghimpunan dan penyaluran dana zakat. Peran masjid sebagai lembaga resmi pengumpul zakat memiliki potensi zakat di indonesia sebesar Rp. 217 Triliun per Tahun. Tentunya potensi tersebut hanyalah angka jika tidak dikelola dengan baik dan efektif. Dalam penelitian ini efektifitas diukur melalui tiga indikator (tepat sasaran, peningkatan ekonomi, pemanfaatan dana). Hasil penelitian sebelumnya menyimpulkan bahwa efekifitas penyaluran zakat di Masjid Taqwa dan Masjid Baiturrahim masih belum efektif karena peningkatan ekonomi bagi mustahiq belum tercapai. Penelitian ini bertujuan untuk mengidentifikasi efektifitas penyaluran zakat pada Masjid Darussalam Kota Wisata Cibubur. Metode penelitian yang digunakan adalah metode penelitian kualitatif deskriptif dengan sumber data primer dan sekunder yang akan di dapatkan dari wawancara, melihat laporan yang berkaitan dengan zakat, observasi, dan dokumentasi kepada Amil di Masjid Darussalam, Kota Wisata, Cibubur.. Hasil penelitian menunjukan bahwa seluruh indikator, yaitu ketepatan sasaran, peningkatan ekonomi, pemanfaatan dana sudah terpenuhi dan penyaluran zakat di Masjid Darussalam berjalan efektif. dengan beberapa catatan yang perlu diperhatikan yaitu pada program ZakatPro harus dilaksanakan pengawasan dan pembinaan dengan seksama agar para mustahik dapat menjadi lebih produktif, serta memberikan solusi dari masing-masing permasalahan usaha para mustahik.
\end{abstract}

Kata Kunci: Efektifitas, Masjid, Penyaluran Zakat 


\section{PENDAHULUAN}

Zakat merupakan salah satu rukun Islam, maka dari itu zakat merupakan kewajiban bagi setiap muslim. Seseorang dapat dikatakan Islam jika dia sudah melaksanakan zakat, dan menjadi indikator kadar keimanan seorang muslim. Zakat juga merupakan salah satu ibadah mahdhah, zakat memiliki beberapa ketentuan meliputi apa saja harta yang terkena zakat, jumlah yang harus dibayarkan, batas paling kecil untuk berzakat, kapan harus dilaksanakan, sampai target penyaluran (Ridlo, 2014). Zakat menjadi ibadah yang sangat penting karena orang-orang yang tidak mau membayar zakat akan merasakan azab yang sangat pedih seperti yang tertuang di QS At-Taubah: 35

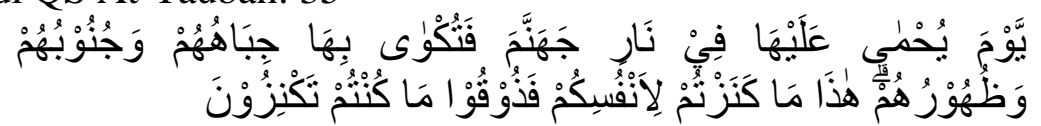

Pada hari ketika (emas dan perak) itu dipanaskan dalam neraka Jahanam lalu disetrikakan (pada) dahi, lambung, dan punggung mereka (seraya dikatakan), "Inilah apa (harta) yang dahulu kamu simpan untuk dirimu sendiri (tidak diinfakkan). Maka, rasakanlah (akibat dari) apa yang selama ini kamu simpan.

Zakat secara bahasa berarti tumbuh dan berkembang. Menurut syari'at, zakat merupakan pengambilan harta kekayaan seseorang yang akan diberikan kepada yang kurang mampu dimana sudah diatur oleh Allah SWT. selain meningkatkan ekonomi, zakat memiliki visi untuk mengendalikan hawa nafsu atas harta di kalangan umat Islam dan memotivasi agar selalu berorientasi sosial. Secara keseluruhan, diharapkan dengan membayar zakat dapat mensucikan harta yanag dimiliki dan ikut merasakan manfaat dana zakat tersebut. secara fungsi untuk memenuhi kebutuhan dasar orang miskin dan kebutuhan sehari-harinya, zakat juga berfungsi untuk mencari solusi atas kemiskinan, pengangguran, hutang dan distribusi pendapatan yang tidak merata. (Nadzri, 2012)

Saat ini penghimpunan dana zakat belum optimal, hal ini terlihat dari penelitian yang dilakukan oleh BAZNAS dan FEM IPB yang menyatakan bahwa total potensi zakat di indonesia sebesar Rp217 triliun namun dana zakat yang berhasil diserap di Indonesia masih berkisar $4,6 \%$ dari potensi zakat nasional. Perbedaan yang sangat jauh antara zakat yang dihimpun dengan potensi zakat menandakan bahwa masih minimnya partisipasi masyarakat muslim untuk menunaikan zakat. (Rulian \& Anggraeni, 2015) 
Masalah lain yang muncul ketika mengelola zakat adalah kualitas dari BAZNAS atau Lembaga Amil Zakat (LAZ) itu sendiri, karena kualitas yang tidak merata, minimnya transparasi pengelolaan zakat, dan belum adanya keberhasilan dalam merubah mustahik menjadi muzakki. Namun, saat ini masalah tersebut lambat laun bisa terselesaikan melihat pertumbuhan badan amil zakat yang cukup signifikan dan perkembangan kualitas badan amil zakat yang semakin membaik. Perkembangan tersebut dapat dilihat dari BAZNAS yang sudah memiliki sertifikasi ISO, hal ini karena BAZNAS merupakan lembaga amil zakat paling transparan. (Rohim, 2020)

Tabel 1. Data Pengumpulan dan Penyaluran Zakat BAZNAS tahun 2019

\begin{tabular}{|c|c|c|}
\hline Tingkatan OPZ & $\begin{array}{c}\text { Pengumpulan } \\
\text { Jumlah Dana }(\mathbf{R p})\end{array}$ & $\begin{array}{c}\text { Penyaluran } \\
\text { Jumlah Dana (Rp) }\end{array}$ \\
\hline BAZNAS & $296,234,308,349$ & $270,716,950,765$ \\
\hline BAZNAS Provinsi & $583,919,722,674$ & $481,796,534,289$ \\
\hline BAZNAS Kabupaten/Kota & 3,539,980,546,6- & $2,586,872,888,35$ \\
\hline LAZ & $3,728,943,985,1 C$ & $3,519,873,720,0 \equiv$ \\
\hline $\begin{array}{l}\text { OPZ Dalam Pembinaan } \\
\text { Kelembagaan }\end{array}$ & $2,078,865,243,74$ & $1,828,861,140,91$ \\
\hline Total & $10,227,943,806,55$ ! & $8,688,221,234,35$ \\
\hline
\end{tabular}

Sumber: Statistik Zakat BAZNAS (2019

Tabel 1 merupakan data yang diperoleh dari statisik zakat tahun 2019 yang dikelola oleh BAZNAS. Dari data tersebut dapat dilihat bahwa dana zakat yang terhimpun dengan total sebesar Rp10,227 triliun dan penyaluran dana zakat dengan total sebesar Rp8,688 triliun dengan daya serap sebesar 94,95\%. Dari Tabel 1 terlihat bahwa dana zakat yang dihimpun selama tahun 2019 sebesar Rp10,227 triliun masihlah sangat jauh jika dibandingkan dengan potensinya yang berjumlah Rp271 triliun. Ini menunjukan bahwa partisipasi masyarakat untuk membayar zakat masih rendah.

Penyaluran zakat merupakan proses, cara, dan perbuatan menyalurkan dana zakat kepada yang berhak untuk menerima dana zakat tersebut. Objek dan sasaran zakat adalah sebagaimana yang tertera dalam Al-Qur'an Surah At-Taubah ayat 60, antara lain: Fakir, Miskin, Amil, Muallaf, Riqob, Ghorimin, Ibnu sabil, dan Fii sabilillah. (Bahri \& Khumaini, 2020). QS At-Taubah: 60 


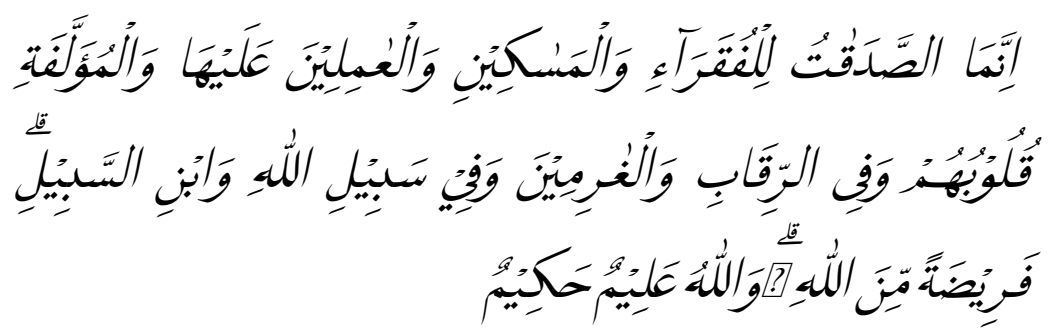

Sesungguhnya zakat itu hanyalah untuk orang-orang fakir, orang-orang miskin, para amil zakat, orang-orang yang dilunakkan hatinya (mualaf), untuk (memerdekakan) para hamba sahaya, untuk (membebaskan) orang-orang yang berutang, untuk jalan Allah dan untuk orang-orang yang sedang dalam perjalanan (yang memerlukan pertolongan), sebagai kewajiban dari Allah. Allah Maha Mengetahui lagi Mahabijaksana.

Kesadaran masyarakat tentang menunaikan zakat sangat penting, tetapi disamping itu penyaluran dana zakat yang dilakukan oleh pengelola masjid harus berjalan dengan efektif. Efektifitas penyaluran dana zakat bisa berjalan beriringan dengan semakin banyaknya lembaga yang memiliki wewenang untuk menghimpun dana zakat dan penyaluran dana zakat ke masyarakat, salah satu lembaga atau tempat untuk menyalurkan dana zakat adalah masjid. UU nomor 23 Tahun 2011 menyatakan bahwa masjid menjadi salah satu tempat untuk mengelola dana zakat, infak, dan sedekah. Dengan kata lain masjid dapat menjadi Unit Pengumpul Zakat (UPZ) yang merupakan bagian dari perpanjangan tangan BAZNAS. Salah satu model penyaluran zakat yang dikembangkan oleh BAZNAS adalah penyaluran dana zakat melalui UPZ dan model penyaluran ini terbukti efektif untuk meningkatkan efektifitas penyaluran zakat, karena dana zakat yang dihimpun oleh muzaki langsung disalurkan kepada mustahik di daerah tersebut. (Supriyadi, 2017)

Efektifitas penyaluran dana zakat dapat terlaksana berkat banyaknya UPZ yang ikut berkontribusi, salah satu bentuk UPZ itu adalah masjid. zakat sebagai UPZ memiliki potensi zakat di Indonesia sebesar Rp. 217 Triliun pertahun. Angka tersebut menunjukan bahwa potensi zakat yang bisa didapatkan dari masjid sangat besar jika memang masing-masing pengelola atau DKM masjid aktif dalam mengkampanyekan penunaian zakat di masjid. (Mukhlis \& Beik, 2013).

Beberapa penelitian mengenai efektivitas penyaluran zakat telah dilakukan, berdasarkan penelitian yang dilakukan oleh Kholijah (2018). Efektifitas penyaluran dana zakat oleh majid dapat dilihat dari 
tiga indikator yaitu, tepat sasaran, peningkatan keimanan, peningkatan ekonomi. Hasil temuan yang dilakukan adalah penyaluran dana zakat dari masjid yang sudah di teliti masih belum efektif karena indikator peningkatan ekonomi masih belum tercapai karena zakat yang dibayarkan untuk mustahiq masih sedikit sehingga sulit untuk meningkatkan indikator peningkatan ekonomi. Menurut peneliti indikator yang digunakan tidak relevan mengingat di Indonesia zakat bukanlah instrumen utama untuk meningkatkan ekonomi para mustahik.

Selanjutnya ada penelitian yang dilakukan oleh Fitria (2016). Pengelolaan zakat fitrah dan zakat maal yang dilakukan oleh Masjid yang telah diteliti telah sesuai dengan prinsip ekonomi syariah, karena dilakukan musyawarah sebelum pengelolaan zakat sesuai dengan Surah At-Taubah ayat 60. Kerjasama organisasi sesuai dengan yang dianjurkan dalam Surah Ash-Shaff ayat 4. Mengelola dana zakat dengan amanah sesuai dengan Surah An-Nisaa ayat 58 dan mengawasi pengelolaan dana zakat agar berjalan sesuai dengan koridor syariah.

Sedangkan penelitian yang dilakukan oleh Arafat (2017). Menemukan hasil bahwa kemauan tinggi para pengelola dana zakat di masjid berbanding terbalik dengan kemampuan sumber daya yang ada, sedangkan kemampuan para pengelola dana zakat masih tergolong minim terutama dalam hal kepekaan tenologi. Kebanyakan dari mereka masih menggunakan metode penyaluran tradisional sehingga penyaluran dana zakat tidak maksimal karena sumber daya yang tersedia masih belum memiliki pengetahuan dan pengalaman yang cukup.

Namun, dari beberapa penelitian terdahulu tentang zakat, masih belum adanya penelitian tentang efektifitas penyaluran zakat yang menggunakan indikator pemanfaatan dana. Fokus permasalan yang ingin dibahas adalah belum adanya pengukuran efektifitas penyaluran zakat yang menggunakan indikator pemanfaatan dana, sedangkan pemanfaatan dana baik dari pihak amil maupun mustahik sangat penting untuk diketahui. 


\section{TINJAUAN LITERATUR Pengertian Zakat}

Secara bahasa zakat berasal dari kata zaka yang berarti suci, baik, berkah, tumbuh, dan berkembang. Sedangkan dari segi istilah, zakat berarti sejumlah harta yang wajib dikeluarkan oleh seseorang yang mencapai kriteria untuk menunaikan zakat dan disalurkan untuk seseorang yang mencapai kriteria untuk menerima zakat. (Mubarok \& Fanani, 2014)

Secara etimologi zakat berarti tumbuh dan berkembang (an-namaa), mensucikan (at-thaharatu), dan berkah (albarakatu). Sedangkan secara terminologis, zakat berarti mengeluarkan sebagian harta dengan syarat-syarat tertentu yang harus dipenuhi agar dapat menunaikan zakat yang nantinya akan disalurkan kepada orang yang berhak menerima zakat. (Romdhoni, 2017). Zakat wajib dilaksanakan seperti yang terdapat di QS Al-Baqarah: 43

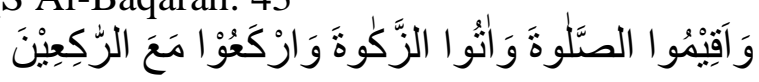

Tegakkanlah salat, tunaikanlah zakat, dan rukuklah beserta orang-orang yang rukuk.

\section{Tujuan Zakat}

Zakat merupakan instrumen yang diciptakan untuk mengentaskan kemiskinan. Tujuan zakat tidak hanya menyantuni mustahik secara konsumtif, tetapi juga memiliki tujuan permanen yaitu zakat dapat mengentaskan kemiskinan dan mengangkat derajat ekonomi dari seorang mustahik menjadi seorang muzaki, maka dari itu pendapatan yang didapat dari zakat juga harus dikelola untuk tujuan produktif. (Wulansari \& Setiawan, 2014)

\section{Penyaluran Zakat}

Zakat yang telah terkumpul oleh Amil selanjutnya akan disalurkan kepada mustahik. Penerima zakat haruslah sesuai dengan yang terdapat di QS At-Taubah: 60 (Maguni, 2013). Golongan yang berhak untuk mendapatkan zakat adalah sebagai berikut :

1. Fakir adalah seseorang yang secara ekonomi dikatakan tidak mampu memenuhi kebutuhannya bahkan untuk menghidupi dirinya sendiri.

2. Miskin adalah seseorang yang mempunyai pekerjaan tetapi kekurangan harta untuk memenuhi kebutuhannya sehari-hari. 
3. Amil adalah seseorang yang diamanahkan untuk mengelola dana zakat di sebuah tempat atau lembaga.

4. Muallaf adalah seseorang yang sebelumnya non-muslim lalu diberikan hidayah oleh Allah SWT untuk masuk kedalam agama Islam.

5. Riqob adalah tindakan untuk membebaskan budak dengan cara membelinya dari pemilik sebelumnya menggunakan dana zakat dengan tujuan agar budak tersebut bisa hidup dengan bebas.

6. Ghorimin adalah tindakan untuk melepaskan seseorang yang sedang terlilit hutang (umumnya riba) menggunakan dana zakat dengan tujuan agar terbebas dari hutang tersebut.

7. Fii Sabilillah adalah orang yang sedang berjuang dijalan Allah, dikatakan bahwa yang dimaksud berjuang di jalan Allah tidak hanya berperang, melainkan juga orang yang sedang menempuh pendidikan.

8. Ibnu Sabil adalah golongan orang yang sedang melakukan perjalanan jauh tetapi tidak memiliki biaya untuk melakukan perjalannya.

\section{Mekanisme Penyaluran Zakat}

Penyaluran zakat kepada mustahik haruslah berdasarkan skala prioritas, dengan memperhatikan prinsip keadilan, dan pemerataan. (Khasanah, 2015). Dalam penyaluran dana zakat diperlukan beberapa tahapan yaitu;

1. mengetahui keberadaan para mustahik

2. kemudian melakukan klasifikasi dan menentukan hak-hak mustahik

3. selanjutnya menghitung jumlah kebutuhan yang diperlukan oleh mustahik kemudian menghitung biaya agar dana zakat dapat tercukupi untuk seluruh mustahik

kemudian dalam menyalurkan dana zakat harus lah sesuai dengan kebutuhan masing-masing mustahik agar tidak terjadi ketimpangan satu sama lain.

\section{Peran Masjid dalam Penyaluran Dana Zakat}

Peran masjid dalam penyaluran dana zakat dapat dilakukan dengan membuat kerjasama dengan lembaga amil zakat yang sudah berpengalaman, jika tidak ada lembaga amil zakat yang bisa diajak 
untuk kerjasama sebaiknya membentuk lembaga amil zakat masjid secara mandiri yang didalamnya merupakan anggota DKM masjid tersebut. jika masjid tidak memiliki lembaga amil zakat di dalamnya, maka penghimpunan dan penyaluran dana zakat tidak akan berjalan, dan fungsi zakat sebagai pemerataan pendapatan tidak akan berjalan. (Novianto \& Nafik HR, 2015).

Kualitas penyaluran zakat pada masjid harus terus ditingkatkan untuk mendorong umat Islam agar mau membayar zakat, rasa tidak percaya masyarakat terhadap lembaga amil zakat menyebabkan keraguan terutama dalam hal transparansi laporan keuangan. Semakin tinggi kualitas penyaluran zakat pada masjid maka akan semakin tinggi pula kepercayaan masyarakat untuk menunaikan zakat di masjid. (Zainal et al., 2016)

\section{Pengertian Efektifitas}

Efektifitas adalah ikatan antara hasil dengan terget sesuai yang direncanakan, suatu kegiatan dapat dikatakan efektif jika sudah mencapai target dan tepat sasaran. Semakin besar hasil yang didapatkan untuk mencapai target dan sasaran yang ditentukan, maka akan semakin efektif kegiatan tersebut. (Handayaningrat, 1996)

Efektifitas adalah sebuah keadaan dimana sampai sejauh mana tujuan dapat tercapai. Semakin banyak rencana yang tercapai maka dapat dikatan bahwa semakin efektif pula kegiatan tersebut, sehingga kata efektifitas juga dapat berarti bahwa tingkat keberhasilan yang dicapai dari suatu rencana dan usaha tertentu sesuai dengan tujuan dari sebuah rencana tersebut. (Azizah, 2018)

Efektifias adalah pemanfaatan sumber daya, sarana dan prasarana dalam jumlah yang telah ditentukan sebelumnya untuk menghasilkan sebuah barang atau jasa yang akan dijalankan. Efektifitas menunjukan keberhasilan berdasarkan capaian yang sudah dilaksanakan. Jika hasil kegiatan tersebut semakin mendekati tujuan yang ingin dicapai, maka akan semakin tinggi nilai efektifitasnya. (Mamuaja, 2016)

\section{Indikator yang Digunakan dalam Penelitian}

Indikator ketepatan sasaran, merupakan indikator yang berkaitan dengan sasaran zakat menurut QS At-Taubah: 60, yaitu fakir, miskin, amil, muallaf, riqob, ghorimin, fii sabilillah, ibnu sabil. Indikator ketepatan sasaran dapat terpenuhi jika dana zakat yang diberikan sesuai dengan yang telah ditentukan dan tidak digunakan 
untuk kegiatan diluar ketentuan ashnaf.

Indikator peningkatan ekonomi, merupakan lanjutan dari indikator tercapainya tujuan, karena tujuan dari zakat secara umum untuk memenuhi kebutuhan sehari-hari para mustahik dan meningkatkan ekonomi seorang mustahik, sehingga indikator peningkatan ekonomi dapat tercapai jika mustahik yang mendapatkan dana zakat mengalami peningkatan secara ekonomi.

Indikator pemanfaatan dana, merupakan indikator yang diambil dari (Mamuaja, 2016) yang menyatakan bahwa efektifitas merupakan pemanfaatan sumber daya, sarana dan prasarana. Indikator ini mengidentifikasi para mustahik dalam menggunakan dana bantuan zakat yang diberikan, apakah dana bantuan tersebut dialokasikan sesuai dengan tujuan diberikannya zakat tersebut. Indikator ini dapat tercapai jika mustahik yang diberikan dana zakat menggunakan dana tersebut sesuai dengan kebutuhan dan tidak digunakan untuk hal bersifat tidak mendesak.

\section{METODOLOGI PENELITIAN}

Metode penelitian yang digunakan pada penelitian ini adalah metode penelitian kualitatif deskriptif dengan pendekatan studi kasus. Menurut Raco (2010). metode kulitatif bisa berarti ganda yaitu teknik atau prosedur, dan gagasan teoritis. Metode yang digunakan merujuk kepada teknik seperti survey, wawancara, dan observasi. Lokasi penelitian ini berada di Masjid Darussalam Kota Wisata Cibubur, Jl. Boulevard Utama No. 1 Kota Wisata, Ciangsana, Bogor.

Objek pada penelitian ini berupa mekanisme penyaluran dana zakat yang sudah dijalankan oleh amil dan mengidentifikasi efektifitas penyaluran dana zakat yang dilakukan oleh amil di Masjid Darussalam Kota Wisata Cibubur. Subjek penelitian ini adalah pihak amil dan pihak mustahik yang merupakan informan atau pihak yang akan memberikan informasi yang dibutuhkan selama penelitian berlangsung untuk mendapatkan temuan dari sebuah fenomena.

Data yang dibutuhkan dalam penelitian ini adalah data primer dan sekunder, data primer merupakan hasil observasi dan wawancara, sedangkan data sekunder merupakan dokumen milik amil atau yayasan. Teknik validitas data yang digunakan pada penelitian ini menggunakan model triangulasi sumber data. Triangulasi sumber data merupakan metode sintesa menggunakan metode pengumpulan data 


\section{HASIL DAN PEMBAHASAN}

\section{Profil Yayasan Darussalam Kota Wisata}

Yayasan Darussalam didirikan pada tahun 2003 dengan memiliki tekad untuk bergerak dalam bidang keagamaan, sosial, dan kemanusiaan. Yayasan Darussalam memiliki tujuan menjadikan Masjid Darussalam Kota Wisata sebagai model pusat kemakmuran masjid menuju kebangkita islam yang kaffah, hal ini dapat terwujud dengan berbagai program ibadah, dakwah, sosial, pendidikan, serta program lainnya.

Dalam melaksanakan penghimpunan dan penyaluran zakat, sebuah instansi, lembaga, maupun yayasan yang diizinkan untuk mengelola, menghimpun, dan menyalurkan dana zakat haruslah memiliki status sebagai lembaga amil zakat. Secara legalitas, Yayasan Darussalam belum memiliki lembaga amil secara mandiri. Saat ini legalitas lembaga amil masihlah berstatus kerjasama dengan Inisiatif Zakat Indonesia atau yang selanjutnya disingkat sebagai IZI. Dalam pengelolaan zakat sendiri saat ini masih menggunakan Amil perseorangan, tetapi dari hasil temuan peneliti pada saat wawancara, Yayasan Darussalam ingin membuat lembaga amil yang mandiri di bawah yayasan pada tahun 2021 "secara legalitas menurut perundang-undangannya, saat ini kita bermitra dengan IZI. Mudah-mudahan tahun ini dapat menjadi Lembaga Amil Zakat setingkat kabupaten."

Jumlah amil di Yayasan Darussalam secara legalitas ada dua orang, sedangkan di Yayasan sendiri ada kepengurusan yang membidangi zakat berjumlah delapan orang. Namun dalam pelaksanaan penyaluran zakat, amil di bantu oleh petugas-petugas yang ada baik dari pihak kepengurusan yayasan ataupun pegawai yang bekerja di Masjid Darussalam, secara legalitas petugas-petugas selain amil yang membantu menyalurkan dana zakat tercatat sebagai sukarelawan.

Status amil di Yayasan Darussalam saat ini tidak tercatat sebagai pegawai, jadi penghasilan amil didapatkan dari zakat saja, tetapi tidak menutup kemungkinan bahwa ada bantuan-bantuan yang diberikan kepada amil dari pihak yayasan. "pengurus tidak mendapatkan fee apapun, karena mereka hanya sebatas relawan saja. Honorer amilnya Cuma dua, yang lainnya tidak dapat." Dari keterangan tersebut, ada perbedaan antara amil dengan kepengurusan yang membidangi zakat, pengurus mendapatkan penghasilan dari 
Yayasan Darussalam dan tidak mendapatkan penghasilan dari dana zakat, sedangkan amil mendapatkan penghasilan dari zakat. Gaji amil yang diambil dari zakat sebesar upah minimun regional daerah tersebut.

\section{Program Penyaluran Zakat pada Masjid Darussalam}

Program penyaluran zakat di Masjid Darussalam tergantung dari seberapa banyak program yang dijalankan oleh Yayasan. Dalam menyalurkan zakat, program yang dirancang sesuai dengan empat pilar yang dimiliki oleh Masjid Darussalam Kota Wisata, empat pilar itu antara lain, pendidikan, dakwah, sosial, dan kemanusiaan. Sehingga program-program penyaluran zakat dapat berbeda satu sama lain sesuai dengan program yang dijalankan pada masing-masing pilar tersebut.

\section{Pilar Pendidikan}

Penyaluran zakat pada pilar pendidikan disalurkan untuk mendukung kegiatan belajar dengan mendanai guru ngaji dan anak-anak sebagai pelajar yang berstatus dhuafa. Fokus dari penyaluran zakat di pilar pendidikan adalah guru dan murid di dalam TPA (Taman Pendidikan Al-Qur'an) yang termasuk kedalam ashnaf fii sabilillah dan dhuafa bagi guru dan murid-murid TPA.

Menurut Irfan Budiman (2021) mengatakan "Di pilar pendidikan, kita salurkan dana zakat untuk membangun ataupun mensupport guru-guru yang mengajar TPA, kemudian anak-anak TPAnya juga secara status merupakan dhuafa". Selain guru dan murid TPA, pilar pendidikan juga memberikan fasilitas kepada pelajar yang mengalami kendala dalam kebutuhan sekolahnya seperti pelunasan hutang sumbangan pembinaan pendidikan, maupun tunggakan yang lainnya.

Berikut pernyataan amil terkait mekanisme penyaluran zakat "Terkait dengan yang pertama pilar pendidikan, apabila ada mustahik yang membutuhkan, biasanya kita akan melakukan seleksi terlebih dahulu dimana para mustahik zakat yang memang dia merasa atau menginginkan adanya bantuan dari lembaga kami, maka dia harus memenuhi persyaratan secara administratif." (Irfan Budiman, 2021)

Program Beasiswa Yatim dan Dhuafa yang full dibiayai oleh zakat termasuk juga kedalam pilar pendidikan. Hal ini diketahui dari hasil wawancara dengan pengurus Program Beasiswa Yatim dan Dhuafa Endang Lukito (2021) mengatakan "Program beasiswa Yatim dan Dhuafa, dalam satu bulan mendapatkan dua ratus ribu rupiah 
belum termasuk kebutuhan kebutuhan sekolah. ada sekitar 162 anak yang pembiayannya full dari zakat". Anak-anak yang tergabung dalam program beasiswa ini haruslah menyetorkan hafalan semampunya setiap pertemuan sebagai bentuk pengabdiannya.

\section{Pilar Dakwah}

Dana zakat yang digunakan dalam pilar zakat merupakan dana bantuan yang diberikan untuk dai yang sedang mengajar di pelosok-pelosok negeri, hal ini diketahui dari wawancara dengan amil yaitu Irfan Budiman (2021) mengatakan "untuk para dai yang memang kita kirim ke pelosok-pelosok untuk melakukan aktifitas dakwah." Dari keterangan tersebut dai yang sedang menjalankan aktifitas dakwah berhak mendapatkan bantuan dana zakat karena termasuk kedalam ashnaf fii sabilillah.

Selain digunakan untuk para dai, dalam pilar dakwah juga terdapat muallaf yang sedang berjuang dalam agama yang baru, para muallaf di Muallaf Center Darussalam mendapatkan bantuan uang setiap dua minggu sekali, besaran jumlahnya tergantung dari usia dan kebutuhan masing-masing muallaf. Tidak hanya berupa uang, bantuan seperti peralatan shalat dan juga peralatan sekolah bagi yang masih berstatus pelajar juga diberikan oleh Yayasan Darussalam, hal ini dikatakan oleh salah satu muallaf di Muallaf Center Darussalam yaitu Lauren (2021) mengatakan "Alhamdulillah terbantu jadi punya banyak teman." Dari keterangan Lauren, Muallaf Center sangat membantu bagi kehidupannya baik secara ekonomi maupun sosial. Namun selain lauren yang masih berstatus pelajar, terdapat juga muallaf yang sudah menikah, jika yang sudah menikah maka bentuk dan jumlah zakat yang diberikan akan berbeda tergantung kebutuhan masing-masing muallaf.

\section{Pilar Sosial}

Pilar sosial merupakan pilar yang menjadi fokus penyaluran dana zakat, program-program sosial yang dijalankan oleh Yayasan Darussalam berjumlah sepuluh program sosial, antara lain:

a. Rumah Singgah Qur'an Yatim dan Dhuafa

b. ATM Beras

c. Bantuan BPJS Kesehatan untuk Dhuafa

d. Beasiswa Yatim dan Dhuafa

e. Pembinaan Dhuafa

f. Layanan Kesehatan Keliling 
g. Layanan Kesehatan Pekanan

h. Perbaikan Rumah Layak Huni

i. Belanja Bareng Yatim

j. Belanja Bareng Jompo

Rumah Singgah Qur'an Yatim dan Dhuafa Darussalam merupakan program Pembinaan untuk anak yatim dan dhu'afa tinggal di Asrama dengan dipenuhi kebutuhan hidupnya meliputi, makan tiga kali sehari, pakaian harian dan sekolah, biaya sekolah, perlatan kebersihan, dan kebutuhan hidup lainnya. Lokasi Rumah Singgah Qur'an Yatim \& Dhua'afa ada di Perumahan Duta Mekar Asri Blok P3 No. 11 RT. 007 RW. 015 Desa Cileungsi kidul, Kecamatan Cileungsi, Kabupaten Bogor. Sedangkan jumlah anak binaan pada tahun 2018 sebanyak lima belas anak, tahun 2019 sebanyak dua puluh anak, dan di tahun 2020 sebanyak dua puluh anak panti ditambah dengan dua puluh lima anak non-panti.

ATM Beras merupakan program santunan berupa beras untuk warga dhuafa dan jompo dengan keterangan sebagai berikut, periode santunan pekanan dengan menempelkan kartu ke ATM Beras yang disediakan, beras yang diterima sejumlah tiga kilogram perpekan. Jumlah penerima manfaat pada tahun 2018 sebanyak seratus delapan puluh tiga orang, tahun 2019 sebanyak seratus delapan puluh tiga orang, tahun 2020 sebanyak seratus delapan puluh tiga orang.

Bantuan BPJS Kesehatan untuk Dhuafa merupakan Program bantuan pembayaran BPJS Kesehatan untuk warga dhuafa dengan bekerjasama antara yayasan dengan pihak BPJS Kesehatan Kabupaten Bogor. Pembayaran dilakukan perenam bulan sekali, penerima manfaat dapat berobat sesuai dengan fasilitas kesehatan yang dipilih menggunakan kartu BPJS tersebut. Jumlah penerima manfaat pada tahun 2018 sebanyak sembilan puluh tujuh orang, tahun 2019 sebanyak sembilan puluh lima orang, dan tahun 2020 sebanyak seratus orang

Program Beasiswa Yatim \& dhuafa melalui program Orang Tua Asuh, selain memberika bantuan beasiswa rutin anak di jenjang SD, SMP, SMA, juga memberikan bantuan dana pendidikan kepada anak yang membutuhkan biaya untuk melanjutkan sekolahnya di jenjang selanjutnya, bantuan uang buku, uang seragam yang diprioritaskan kepada anak anak yang dhuafa, yatim dan berprestasi khususnya yang sudah menjadi anak asuh dalam binaan program OTA Masjid Darussalam. Penerima Manfaat pada tahun 2018 sebanyak 
enam belas siswa, tahun 2019 sebanyak enam belas siswa, dan di tahun 2020 sebanyak enam belas siswa.

Program Pembinaan Dhuafa merupakan program pembinaan keislaman yang meliputi, aqidah, akhlak, ibadah juga kegiatan pelatihan wirausaha untuk para dhu'afa yang dilakukan pekanan, selain itu mereka juga mendapatkan santunan sembako rutin dua kali dalam satu tahun. Jumlah penerima manfaat pada tahun 2018 sebanyak dua ratus tujuh puluh satu orang, tahun 2019 sebanyak dua ratus tujuh puluh satu orang, dan di tahun 2020 sebanyak dua ratus tujuh puluh satu orang.

Program Layanan Kesehatan Keliling merupakan layanan kesehatan yang diberikan secara cuma-cuma dengan langsung mengunjungi rumah warga, program ini meliputi, edukasi kesehatan, pemeriksaan kesehatan dan pengobatan, dan pemberian makanan bergizi. Penerima manfaat pada tahun 2018 sebanyak dua ratus tujuh puluh sembilang orang, tahun 2019 sebanyak delapan ratus empat puluh lima orang, dan di tahun 2020 belum dapat berjalan karena kondisi yang tidak memungkinkan.

Program Layanan Kesehatan Pekanan merupakan program layanan kesehatan untuk warga yang mengikuti pembinaan rutin bagi warga dhuafa. Pemeriksaan dilakukan pekanan dengan fasilitas penerimaan obat, dan rujukan bila dibutuhkan untuk ke rumah sakit. penerima manfaat pada tahun 2018 sebanyak tiga ratus sembilan puluh dua orang, tahun 2019 sebanyak tiga ratus enam belas, dan di tahun 2020 sebanyak seratus delapan orang.

Program Renovasi Rumah Layak Huni merupakan program bantuan berupa perbaikan rumah yang tidak layak huni menjadi layak untuk dihuni kembali untuk warga dhuafa. Program mulai dilaksanakan pada tahun 2020 dengan penerima manfaat sejumlah 3 Kepala keluarga, pertama Ibu Fani - Perumahan Pondok Gede Permai, Kel. Pasar Rebo Kec. Jati Asih. Kedua Bapak Timan - Kp.Pabuaran Wetan RT 02/RW 05 Dusun 4 Ciangsana Gunung Putri. Ketiga Bapak Onim Kp. Pabuaran Wetan Dusun 4 RT 02/17 Ciangsana, Gunung Putri.

Belanja Bareng Yatim adalah program santunan yatim dan dhuafa dengan langsung berbelanja di toko yang ditunjuk sesuai kebutuhan masing-masing yang dilaksanakan setiap satu bulan. Jumlah penerima manfaat pada thaun 2018 sebanyak tujuh puluh sembilan anak, tahun 2019 sebanyak tujuh puluh sembilan anak, dan di tahun 2020 sebanyak tujuh puluh sembilan anak. 
Belanja Bareng Jompo adalah program santunan untuk jompo dhuafa dengan langsung berbelanja di toko yang ditunjuk sesuai kebutuhan masing-masing. Program dilakukan setiap 6 bulan sekali. Jumlah penerima manfaat pada tahun 2018 belum ada, tahun 2019 sebanyak tujuh puluh satu orang, dan di tahun 2020 sebanyak seratus tiga puluh lima orang.

Tabel 3. Penerima Manfaat Program Sosial Darussalam tahun 2018-2020

\begin{tabular}{|clccc}
\hline \multirow{2}{*}{ No } & \multicolumn{1}{|c}{ Program Sosial } & \multicolumn{3}{c}{ Penerima Manfaat } \\
& & 2018 & 2019 & 2020 \\
\hline 1 & Rumah Qur'an Yatim \&Dhuafa & 15 & 20 & 45 \\
2 & ATM Beras & 183 & 183 & 183 \\
& Bantuan BPJS Kesehatan & & & \\
3 & Dhuafa & 97 & 95 & 100 \\
4 & Beasiswa Yatim \& Dhuafa & 16 & 16 & 16 \\
5 & Layanan Kesehatan Keliling & 279 & 845 & 0 \\
6 & Layanan Kesehatan Pekanan & 392 & 316 & 108 \\
7 & Renovasi Rumah Layak Huni & 0 & 0 & 3 \\
& Belanja Bareng Yatim \& & & & \\
8 & Dhuafa & 79 & 79 & 79 \\
9 & Belanja Bareng Jompo & 0 & 71 & 135 \\
10 & Pembinaan Dhuafa & 271 & 271 & 271 \\
\hline \multicolumn{2}{|c}{ Total } & 1332 & 1896 & 940 \\
\hline
\end{tabular}

Tabel 3 diambil dari Laporan Kegiatan Sosial Periode Tahun 2018-2020 yang menunjukan bahwa jumlah penerima manfaat program sosial pada tahun 2018 sebanyak seribu tiga ratus tiga puluh dua orang, tahun 2019 sebanyak seribu delapan ratus sembilan puluh enam orang, dan di tahun 2020 sebanyak sembilan ratus empat puluh orang, dengan jumlah total selama tiga tahun sebesar empat ribu seratus enam puluh delapan orang.

Salah satu program sosial yang baru berjalan pada tahun 2021 adalah program ZakatPro yang bertujuan untuk meningkatkan taraf hidup mustahik dengan memberikan bantuan modal kepada mustahik yang memiliki kemampuan tetapi tidak memiliki dana untuk menjalankan sebuah usaha, sesuai dengan keterangan amil saat diwawancarai.

"Zakatpro masuk ke dalam program pemberdayaan dimana masuk ke bagian sosial, untuk zakpro ini dimana jika memang penyaluran zakat yang diberikan kepada mustahik yang membedakan adalah dimana kita melakukan pendampingan dan monitoring, untuk 
zakpro juga kita batasi usia-usia produktif, dimana mereka masih mempunyai kekuatan atau keinginan usaha untuk membuka usaha-usaha lalu sehingga dia memberdayakan dirinya sendiri." (Irfan Budiman, 2021)

\section{Pilar Kemanusiaan}

Program pada pilar kemanusiaan sebenarnya adalah program yang bersifat insidensial seperti banjir, longsor, gempa bumi, dan bencana alam maupun bencana kemanusiaan lainnya. Yayasan Darussalam akan mengadakan penggalangan dana dan mengirimkan relawan ke tempat terjadinya bencana alam tersebut, bantuan yang diberikan biasanya berupa makanan, pakaian, alat shalat, dan kebutuhan lainnya yang diperlukan. Penyaluran zakat diberikan kepada para relawan yang dikirim oleh yayasan untuk membantu korban bencana alam.

Irfan Budiman (2021) mengatakan "kita menyalurkan zakat untuk saudara-saudara kita di palestina, kemudian juga di rohingya yang itu masuk dalam salah satu ashnaf penyaluran zakat." Dari keterangan tersebut, penyaluran zakat juga digunakan untuk bencana kemanusiaan berupa konflik yang terjadi di negara lain, seperti yang dilakukan pada bulan puasa tahun 2021 .

\section{Ketepatan Sasaran dalam Penyaluran Zakat}

Sasaran zakat dalam islam tertuang di dalam QS At-Taubah: 60, Golongan yang yang berhak menerima zakat sesuai dengan ayat tersebut adalah fakir, miskin, amil, muallaf, riqob, ghorimin, fii sabilillah, ibnu sabil. Selain itu, dana zakat tidak boleh digunakan selain untuk golongan yang tidak disebutkan dalam ayat tersebut. Dana zakat boleh digunakan diluar delapan golongan apabila ada unsur urgensi dan sesuai dengan kesepakatan para ulama.

Penetapan sasaran zakat di Masjid Darussalam Kota Wisata adalah para mustahik di tiga desa sekitar Masjid Darussalam, yaitu desa ciangsana, desa nagrak, dan desa limus nunggal. Yayasan Darussalam bekerja sama dengan kepala desa untuk melakukan pendataan untuk mencari mustahik, dari database tersebut barulah Yayasan Darussalam dapat menyalurkan zakat sesuai dengan kebutuhan masing-masing individu. Hal ini diketahui dari hasil wawancara dengan amil yaitu Irfan Budiman (2021) mengatakan "di Yayasan Darussalam sudah menentukan setiap tahunnya prioritas desa yang dekat dengan Masjid Darussalam, diataranya ada desa ciangsana, desa nagrak, dan desa limus nunggal". 
Setiap program yang berkaitan dengan zakat dibuat sesuai target sasaran pada masing-masing ashnaf, pada program ATM Beras misalnya, seluruh mustahik yang berada di dalam wewenang Masjid Darussalam dapat memperoleh beras kapanpun sesuai dengan kebutuhannya, program ini memiliki target fakir dan miskin. Seorang amil juga mendapatkan gaji atau penghasilan dari zakat itu sendiri. Selanjutnya ada program Muallaf Center Masjid Darussalam, program ini memiliki target sasaran yaitu para muallaf yang berstatus kurang mampu, para muallaf dibimbing secara keagamaan dan diberikan bantuan berupa uang setiap dua minggu, pemberian alat shalat, dan kebutuhan lainnya. Selanjutnya ada program pendidikan dimana sasaran zakat yang dituju adalah para guru yang mengajar di TPA Darussalam, dan para dai yang dikirim oleh Yayasan Darussalam untuk melakukan aktifitas dakwah di pelosok-pelosok negeri. Para guru dan dai masuk kedalam ashnaf fii sabilillah. Yayasan Darussalam juga memiliki program sosial dimana program ini memiliki sasaran yaitu seseorang yang sedang memiliki hutang atau tunggakan yang harus segera dibayarkan, program sosial memiliki target ashnaf Ghorimin.

Berdasarkan temuan dalam proses pengumpulan data yang dilakukan oleh peneliti, program penyaluran zakat yang dilakukan oleh Amil Yayasan Darussalam hampir memenuhi seluruh ashnaf, antara lain fakir, miskin, amil, muallaf, ghorimin, dan fii sabilillah. Dana zakat yang terkumpul juga digunakan sesuai dengan ashnaf, tidak ada dana zakat yang dikeluarkan untuk kebutuhan lain.

Sesuai dengan QS At-Taubah: 60 tentang golongan yang berhak menerima zakat, dan teori efektifitas dari (Handayaningrat, 1996) yaitu suatu kegiatan dapat dikatakan efektif apabila sudah mencapai target dan tepat sasaran. Peneliti menyimpulkan bahwa penyaluran zakat pada Masjid Darussalam Kota Wisata Cibubur sudah sesuai dan memenuhi indikator ketepatan sasaran.

\section{Peningkatan Ekonomi bagi Mustahik Zakat}

Peningkatan ekonomi merupakan salah satu dari tujuan zakat, peningkatan ekonomi merujuk pada teori (Azizah, 2018) yang menyatakan bahwa efektifitas adalah sebuah keadaan dimana sampai sejauh mana tujuan dapat tercapai. Tujuan zakat tidak hanya menyantuni mustahik secara konsumtif, tetapi juga memiliki tujuan permanen yaitu zakat dapat mengentaskan kemiskinan dan mengangkat derajat ekonomi dari seorang mustahik menjadi seorang 
muzaki (Wulansari \& Setiawan, 2014).

Peningkatan ekonomi merupakan kenaikan tafar hidup seseorang baik secara signifikan maupun secara tidak signifikan, peningkatan ekonomi ditandai dengan adanya kebebasan finansial di suatu bidang kebutuhan yang sebelumnya terasa sulit menjadi terasa lebih baik. Peningkatan ekonomi dapat disebabkan oleh naiknya penghasilan seseorang atau mendapatkan bantuan dari orang lain.

Mekanisme penyaluran zakat bisa berbeda tergantung dari pilar mana yang akan dibantu oleh zakat. Setiap pilar memiliki program kerja masing-masing dengan jumlah yang bervariasi. Pertama yang dilakukan oleh amil adalah menerima laporan bantuan yang diberikan oleh mustahik, di beberapa program ada mustahik yang sudah terdaftar di database mustahik sehingga sudah terseleksi. Selanjutnya musthaik menyiapkan dokumen-dokumen yang menjadi persyaratan, lalu amil akan melakukan Assesment atau survey untuk mengetahui kebenaran dan menjadi uji kelayakan bagi mustahik yang menjadi akan mendapatkan bantuan zakat. Setelah dirasa layak untuk mendapatkan bantuan, selanjutnya amil menyiapkan beberapa dokumen untuk diajukan ke yayasan bahwa mustahik yang mengajukan bantuan layak untuk mendapatkan bantuan zakat. Setelah yayasan dan pengurus menyetujui pengajuan yang diberikan oleh amil, langkah terakhir yang dilakukan oleh amil yaitu memberikan dana bantuan sesuai yang dibutuhkan, bisa berupa pelunasan hutang rumah sakit, pelunasan hutang biaya sekolah, pemberian bantuan modal usaha, dan lain-lain sesuai dengan masing-masing program yang dijalankan.

Dampak penyaluran zakat yang dirasakan oleh para mustahik dengan program Muallaf Center cukup terasa walaupun tidak signifikan hal ini diketahui dari hasil wawancara dengan Lauren selaku Muallaf yang mengatakan "iya ada (peningkatan ekonomi) dari sebelumnya, misalnya buat sekolah beli kuota biasanya tidak jajan ngumpulin, sekarang sudah ada duitnya." Selanjutnya pada program Beasiswa Yatim dan Dhuafa Darussalam juga merasakan adanya kenaikan taraf hidup, hal ini diketahui berdasarkan hasil wawancara dengan salah satu penerima manfaat yaitu Muhammad Iqbal Al-Ghifari yang mengatakan "Lebih ngerasa uang jajan dapet lebih jadi ketika jajan tidak perlu mikirin uang buat jajan, lebih merasa sudah bisa ngasih ke orang tua gitu." Lalu ada program ZakatPro yang memiliki tujuan mengubah mustahik menjadi muzakki, namun peningkatan ekonomi belum pada program ini karena berdasarkan 
hasil temuan peneliti mengungkapkan bahwa bantuan modal yang diberikan tidaklah menyelesaikan permasalahan utama yaitu hilangnya pelanggan karena pandemi. Temuan ini ditegaskan dengan hasil wawancara dari Ibu Tarianti selaku penerima modal yang mengatakan "sebetulnya membantu sekali dalam bentuk modal, tetapi karena keadaannya berbeda tidak kaya dulu. Sasaran saya kan ibu-ibu sementara sekarangkan ibu-ibu ngumpul ngga boleh."

Peneliti menyimpulkan bahwa indikator peningkatan ekonomi sudah tercapai, hal ini dapat terbukti karena dari ketiga program tersebut, dua diantaranya mengalami peningkatan ekonomi. Khusus program ZakatPro yang menyalurkan zakat dengan tujuan produktif masihlah memiliki kekurangan dimana mustahik hanya sebatas diberikan bantuan modal usaha saja, sedangkan yang mereka butuhkan adalah solusi agar mereka bisa bertahan disituasi yang saat ini sedang sulit.

\section{Pemanfaatan Dana Zakat oleh Mustahik}

Efektifias menurut (Mamuaja, 2016) adalah pemanfaatan sumber daya, sarana dan prasarana dalam jumlah yang telah ditentukan sebelumnya untuk menghasilkan sebuah barang atau jasa yang akan dijalankan, sedangkan sumber daya dalam hal ini adalah zakat itu sendiri baik berupa barang maupun uang. (Wulansari \& Setiawan, 2014) juga mengatakan bahwa pendapatan yang didapat dari zakat juga harus dikelola untuk tujuan produktif.

Penyaluran zakat pada Yayasan Darussalam biasanya tidak berupa uang, melainkan berupa bantuan yang diberikan sesuai kebutuhan, misalnya ada mustahik yang mengajukan pelunasan uang bulanan sekolah maka pihak Yayasan Darussalam akan memberikan bantuan berupa pelunasan langsung ke pihak sekolah, bukan dalam bentuk uang yang diberikan kepada mustahik untuk dibayarkan ke sekolah. Hal ini dimaksudkan agar tidak ada penyalahgunaan yang dilakukan oleh mustahik. Berbeda dengan program yang lain, program ZakatPro memberikan bantuan modal usaha dalam bentuk uang yang dimaksudkan untuk kegiatan produktif mustahik, jika uang yang diberikan tidak digunakan untuk modal usaha yang sedang dijalankan, maka mustahik tidak memanfaatkan dana tersebut sesuai dengan yang diberikan oleh pihak Yayasan Darussalam.

Pemanfaatan dana merupakan cara mustahik dalam 
mengelola uang yang didapatkan dari dana zakat, pemanfaatan dana dapat dikatakan efektif jika uang yang didapatkan dikelola sesuai dengan maksud diberikannya uang tersebut. Jika uang tersebut dimaksudkan untuk kebutuhan sehari-hari maka uang itu harus dikeluarkan untuk kebutuhan sehari-hari, para muallaf yang berada di bawah naungan Muallaf Center mendapatkan uang karena selain muallaf, mereka juga tergolong sebagai dhuafa, jadi uang yang diberikan haruslah digunakan untuk kebutuhan sehari-hari. Begitupun dengan program Beasiswa Yatim dan Dhuafa, para mustahik mendapatkan uang untuk digunakan dalam memenuhi kebutuhan sehari-hari dan kebutuhan sekolah. Berbeda dengan program ZakatPro, uang yang diberikan khusus untuk modal usaha.

Hasil temuan selama proses pencarian data terkait pemanfaatan dana, peneliti mendapatkan hasil berupa pernyataan dari masing-masing mustahik pada beberapa program. Pada program Rumah Singgah Qur'an Yatim dan Dhuafa peneliti mewawancarai salah satu penghuni yaitu Rizal Rinandi yang mengatakan "uang saku kita tabungin buat kebutuhan sekolah, tidak jajan." Selanjutnya ada lauren dari Muallaf Center Darussalam yang mengatakan "uangnya dipake buat kebutuhan aja di rumah." Lalu ada Putra Wahyu Hidayah selaku penerima Beasiswa Yatim dan Dhuafa mengatakan "pastinya buat kuota karena kita tidak mungkin menghandle sendiri, orang tua juga pasti butuh buat kebutuhan yang lain." Dan juga Muhammad Al-Ghifari selaku penerima Beasiswa Yatim dan Dhuafa yang mengatakan "kan ada empat ratus, dua ratus saya, dua ratus saya kasih orang tua. Sebenarnya tidak dipakai sih cuman dikumpulin saja karenakan kalo anak pesantren jarang jajan, jadi dikumpulin saja." Begitupun dengan Ibu Tarianti yang mendapatkan bantuan modal dari program ZakatPro langsung direalisasikan begitu sudah mendapatkan uang, pernyataan ini dibuktikan dengan hasil wawancara yang mengatakan "digunakan untuk tambahan modal usaha, sudah direalisasikan. Masih sisa dua puluh ribu".

Berdasarkan teori efektifitas yang dikemukakan oleh (Mamuaja, 2016) dan pernyataan (Wulansari \& Setiawan, 2014) mengenai pemanfaatan dana, peneliti menyimpulkan bahwa indikator pemanfaatan dana sudah tercapai. Hal ini dapat dibuktikan dengan hasil wawancara yang menunjukkan kesesuaian dalam menggunakan uang yang diberikan oleh Yayasan Darussalam sesuai kebutuhannya masing-masing, terutama pada program ZakatPro yang memang diperuntukkan untuk kegiatan produktif, dan tidak adanya mustahik 
yang menggunakan dana zakat selain untuk kebutuhan sehari-hari.

\section{SIMPULAN}

Mekanisme penyaluran zakat bisa berbeda tergantung dari pilar mana yang akan dibantu oleh zakat. Pertama yang dilakukan oleh amil adalah menerima laporan bantuan yang diberikan oleh mustahik, di beberapa program ada mustahik yang sudah terdaftar di database mustahik sehingga sudah terseleksi. Selanjutnya musthaik menyiapkan dokumen-dokumen yang menjadi persyaratan, lalu amil akan melakukan Assesment atau survey untuk mengetahui kebenaran dan menjadi uji kelayakan bagi mustahik yang menjadi akan mendapatkan bantuan zakat. Setelah dirasa layak untuk mendapatkan bantuan, selanjutnya amil menyiapkan beberapa dokumen untuk diajukan ke yayasan bahwa mustahik yang mengajukan bantuan layak untuk mendapatkan bantuan zakat. Setelah yayasan dan pengurus menyetujui pengajuan yang diberikan oleh amil, langkah terakhir yang dilakukan oleh amil yaitu memberikan dana bantuan sesuai yang dibutuhkan. Penyaluran zakat pada pilar pendidikan biasanya digunakan untuk guru dan murid yang berada di TPA Yayasan Darussalam. Pada pilar dakwah, dana zakat digunakan untuk para dai yang diberikan tugas untuk berdakwah di pelosok-pelosok negeri. Pilar sosial menjadi pilar utama dalam penyaluran dana zakat, biasanya digunakan untuk kesejahteraan mustahik, seperti ATM beras, beasiswa, bantuan modal, dan lain-lain. Yang terakhir ada pilar kemanusiaan dimana biasanya dana zakat digunakan untuk relawan yang pergi ke tempat bencana alam.

Penyaluran zakat pada Masjid Darussalam Kota Wisata sudah berjalan efektif karena memenuhi ketiga indikator yang digunakan dalam penelitian ini yaitu ketepatan sasaran, peningkatan ekonomi, dan pemanfaatan dana. Ketepatan sasaran dapat terbukti dari tidak adanya penyaluran dana untuk selain ashnaf zakat. peningkatan ekonomi dapat dibuktikan dari adanya peningkatan taraf hidup para mustahik, dan pemanfaatan dana dapat dibuktikan dengan tidak adanya mustahik yang menggunakan dana zakat diluar ketentuan yang telah diberikan. 


\section{REFERENSI}

Azizah, S. N. (2018). Efektivitas Kinerja Keuangan Badan Amil Zakat Nasional (Baznas) pada Program Pentasharufan Dana Zakat di Baznas Kota Yogyakarta. El-Jizya: Jurnal Ekonomi Islam, 6(1), 91-112. https://doi.org/10.24090/ej.v6i1.2049

Bahri, E. S., \& Khumaini, S. (2020). Analisis Efektivitas Penyaluran Zakat pada Badan Amil Zakat Nasional. Al Maal: Journal of Islamic Economics and Banking, 1(2), 164. https://doi.org/10.31000/almaal.v1i2.1878

Handayaningrat, S. (1996). Pengantar Ilmu Administrasi Negara dan Manajemen. In PT. Gunung Agung (Vol. 1, Issue 1). https://doi.org/10.35794/emba.v1i4.2699

Khasanah, Y. (2015). Mekanisme Penghimpunan Dan Pendistribusian Dana Zakat, Infaq, Dan Shadaqah (Zis) Untuk Anak Yatim Piatu Pada Divisi Sosial Baitul Maal Di KJKS BMT Muamalat Limpung. In Walisongo Institutional Repository (Vol. 1, Issue c). Walisongo Institute.

Maguni, W. (2013). Peran Fungsi Manajemen Dalam Pendistribusian Zakat: Distribusi Zakat Dari Muzakki Ke Mustahik Pada ( Badan Amil Zakat ) Baz. Jurnal Al-'Adl, 6(1), 157-183.

Mamuaja, B. (2016). Analisis Efektivitas Penerapan Sistem Pengendalian Intern Terhadap Kinerja Instansi Pemerintah Di Dinas Pendapatan Kota Manado. Jurnal $E M B A$, 4(1), 165-171. https://ejournal.unsrat.ac.id/index.php/emba/article/view/ 11583 
Mubarok, A., \& Fanani, B. (2014). Penghimpunan Dana Zakat Nasional (Potensi, Realisasi dan Peran Penting Organisasi Pengelola Zakat). Permana, 5(2), 7-16.

Mukhlis, A., \& Beik, I. S. (2013). Analisis Faktor-faktor yang Memengaruhi Tingkat Kepatuhan Membayar Zakat: Studi Kasus Kabupaten Bogor. Al-Muzara'ah, 1(1), 83-106. https://doi.org/10.29244/jam.1.1.83-106

Nadzri, F. A. A. (2012). Zakat and Poverty Alleviation: Roles of Zakat Institutions in Malaysia. International Journal of Arts and Commerce, 1(7), 61-72.

Novianto, H. R., \& Nafik HR, M. (2015). Mengapa Masyarakat Memilih Menunaikan Zakat di Masjid Dibandingkan Dengan Lembaga Zakat? (Studi Kasus Pada Masyarakat Desa Kramat Jegu Kecamatan Taman Kabupaten Sidoarjo). Jurnal Ekonomi Syariah Teori Dan Terapan, 1(3),

221.

https://doi.org/10.20473/vol1iss20143pp221-236

Ridlo, A. (2014). Zakat dalam Perspektif Ekonomi Islam. Al-Adl, 7(1), 203.

Rohim, A. N. (2020). Revitalisasi Peran dan Kedudukan Amil Zakat dalam Perekonomian. Journal of Islamic Economics and Finance Studies, 1(1), 41. https://doi.org/10.47700/jiefes.v1i1.1925

Romdhoni, A. H. (2017). Zakat Dalam Mendorong Pertumbuhan Ekonomi Dan Pengentasan Kemiskinan. Jurnal Ilmiah Ekonomi Islam, 3(01), 41. https://doi.org/10.29040/jiei.v3i01.98

Rulian, N. A., \& Anggraeni. (2015). Analisis Faktor-faktor yang Memengaruhi Muzaki dalam Memilih Organisasi 
Pengelola Zakat (OPZ): Studi Kasus di Badan Amil Zakat Nasional Kota Bogor. Al-Muzara'ah, 3(1), 20-33. https://doi.org/10.29244/jam.3.1.20-33

Supriyadi, A. (2017). Pemberdayaan Ekonomi Berbasis Masjid(Studi Kritis Pasal 53, 54, Dan 55 Pp. Nomor14 Tahun 2014 Tentang Pelaksanakaan Uu Nomor 23 Tahun 2011Tentang Pengelolaan Zakat). An-Nisbah: Jurnal Ekonomi Syariah, 3(2). https://doi.org/10.21274/an.2017.3.2.210-229

Wulansari, S. dwi, \& Setiawan, A. H. (2014). Analisis Peranan Dana Zakat Produktif Terhadap Perkembangan Usaha Mikro Mustahik ( Penerima Zakat ). Diponegoro Journal of Economics, 3(1), 1-15. https://ejournal-s1.undip.ac.id/index.php/jme

Zainal, H., Abu Bakar, A., \& Saad, R. A. J. (2016). Reputation, Satisfaction of Zakat Distribution, and Service Quality as Determinant of Stakeholder Trust in Zakat Institutions. International Journal of Economics and Financial Issues, 6(7Special Issue), 72-76. 